Revista de Dialectología y Tradiciones Populares, vol. LXIV, n. ${ }^{\circ}$ 1, pp. 177-210, enero-junio 2009, ISSN: 0034-7981, eISSN: 1988-8457, doi: $10.3989 /$ rdtp.2009.026

\title{
El agua que cura
}

\section{Healing Waters}

\author{
María Cátedra Tomás \\ Departamento de Antropología Social \\ Facultad de Ciencias Políticas y Sociología \\ Universidad Complutense de Madrid
}

\section{RESUMEN}

Focalizando la reflexión en cuatro balnearios diferentes - dos en España y dos en Portugal-, el artículo muestra las múltiples mediaciones sociales que operan en la terapéutica del agua en diferentes contextos: desde el uso local inserto en saberes populares, incluyendo lo lúdico en lo terapéutico que puede conectarse con la ilusión de un regreso a la naturaleza cuando ésta ya ha dejado de ser "natural", a otros en los que el ocio es expresión de un estilo de vida exclusivo que incluye un acercamiento al paisaje como parte de la estética de una época y como refugio ante el stress urbano. Se observa así cómo estos usos del agua, que permiten concebir los balnearios bien como sanatorios de la naturaleza bien como negocios en los que el poder médico se pliega al de promotores turísticos convertidos en asesores de salud, se vinculan a concepciones diferentes no sólo del agua, sino de la sociedad misma y sus diferentes grupos.

Palabras clave: Simbolismos del agua; Antropología y aguas termales; Balnearios de España y Portugal; Turismo y salud.

\section{SUMMARY}

Based on fieldwork in four different spas - two in Spain and two in Portugal- this paper shows the mutiple social mediations operating in water therapies in different contexts: from the local use inscribed in popular knowledge, including playful elements inserted in therapeutic practices under the illusion of a return to nature when nature itself has stopped being "natural", to others in which leisure time is an expression of an exclusive life style including a reevaluation of landscape as part of a time-bound aesthetics and as a refuge from urban stress. These different uses of water allow us to understand spas both as nature sanatoriums as well as a form of business where medical power bends to the interests of turistic enterpreneurs transformed into health advisors, linked to different conceptions not only of water but also of society itself.

Key Words: Water Symbolism; Anthropology and Termalism; Spanish and Portuguese Spas; Turism and Healt. 


\section{INTRODUCCIÓN}

Todo un lado de nuestra alma nocturna se explica por el mito de la muerte concebida, como una partida en el agua. Para el soñador, las inversiones entre esa partida y la muerte son continuas. Para ciertos soñadores, el agua es el movimiento nuevo que nos invita a un viaje nunca realizado. Esa partida materializada nos arranca a la materia de la tierra.

Gastón Bachelard, El agua y los sueños.

El agua es una sustancia transparente, incolora, inodora e insípida, tal como aprendimos en la escuela. El agua a primera vista parecería algo neutral, un mero elemento de la naturaleza. Y sin embargo, desde la perspectiva de las ciencias sociales es un poderoso objeto intelectual que tiene el poder de minar, de disolver, y de corroer las fronteras entre las disciplinas, las ópticas obligadas, las problemáticas convenidas (Lenclud 1984, Durand 2003). La hidráulica es al mismo tiempo algo sagrado, político, militar, industrial, científico, sanitario, económico, tiene que ver con la ecología, con los placeres y sentidos del cuerpo, con los comportamientos y la sociabilidad, con ideas y valores, símbolos y metáforas. El agua es natura pero también, decisivamente, es cultura.

El agua ha unido al hombre, la naturaleza y la cultura de un modo indisoluble. Se ha utilizado tanto para nacer como para morir, al integrar al niño al mundo de los seres humanos a través del bautismo como para despedir a los muertos lavándolos en su último viaje, purifica a los que cambian de estado, bendice casas, barcos, campos o animales y simboliza al propio Dios ("Yo soy agua viva"). La imagen del paraíso está llena de ríos y también su pérdida, anegada por el diluvio. Todos los muertos indo-germánicos —desde los griegos a los índicos, nórdicos y celtas - peregrinan a través del mismo paisaje funerario en su camino al más allá y siempre al final del viaje se llega a un cuerpo de agua —océano, río, bahía- (Illich 1989: 55). Las fuentes, ríos o lagos sagrados, tan numerosos en la cristiandad medieval, nos recuerdan que el agua es símbolo de gracia, un reflejo de un principio eterno.

Quizá por esta razón las aguas sanadoras se han asociado con tanta frecuencia a las divinidades y han adquirido un cierto carácter sagrado presente en la toponimias - como Fuensanta- y su reiterada asociación con imágenes religiosas, especialmente la Virgen (por ejemplo la Virgen de las Aguas o Nuestra Señora de las Fuentes en Ávila). Muy a menudo ermitas y santuarios cuentan con una fuente sanadora en sus inmediaciones. Una va- 
riedad de esas aguas que curan son las aguas termales, a las que me voy a referir a continuación ${ }^{1}$.

Como ha mostrado Vigarello, tras la extensa utilización de las aguas

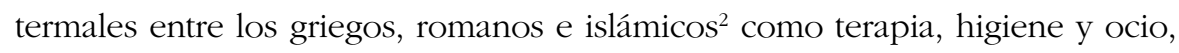
y su utilización como juego, diversión y trasgresión en la Edad Media, se producirá una progresiva intolerancia al agua posteriormente. El alegre lema de los bañeros alemanes en el siglo Xv ("Agua por fuera, vino por dentro, estemos contentos") se vuelve impensable en los siglos XVI y XVII cuando el agua se percibe como una sustancia capaz de infiltrarse en el cuerpo; el agua caliente hace frágil los órganos, deja abiertos los poros a los aires malsanos, provoca fisuras que la peste aprovecha. Así el agua tiene pues una estrecha relación con el cuerpo, sus límites, sus apariencias y sus mecanismos internos: el cuerpo viene a ser un lugar corruptor, turbulento y violento además de poroso. En ciertos casos, como en la hidroterapia, el agua puede restituir densidad a los cuerpos "demasiado secos" y corregir ciertos humores ácidos, con ciertas obligaciones (reposo, protección), pero en general los baños sientan mal, invaden, estropean, desequilibran y se abren a peligros, trasmiten contagios. Por ello es una práctica rara que desaparece a partir del siglo XV cuando la limpieza de la ropa equivale a la de la persona (Vigarello 1985: 29, 89).

En el siglo XVIII el baño caliente adquiere una nueva presencia si bien queda reservado a los nobles. Se supone que el agua caliente hace circular los humores pero es fundamentalmente objeto de placer. Una interesante y

\footnotetext{
${ }^{1}$ Este ensayo forma parte del Proyecto "Prejubilados españoles: políticas sociales para la reorganización del tiempo y de los espacios públicos" (SEJ2204-05327/SOCI). Agradezco a su Investigador Principal, José Luis García García la atenta y dedicada lectura de estas páginas. Y también a otros dos miembros del equipo, Marie José Devillard y Mónica Cornejo que me acompañaron en alguna de las visitas al balneario. Una primera y muy reducida versión de este ensayo fue expuesta en la Mesa Redonda "Los mitos del agua" de la EXPO de Zaragoza con el título: "El simbolismo de las aguas sanadoras en España" (Ágora de la Tribuna del Agua, 7 de agosto de 2008). Agradezco a Noni Venegas y a Javier Conde su amable invitación a participar en la misma junto a los otros dos coparticipantes, María Fernanda de Santiago e Ignacio Gómez de Liaño. Mi agradecimiento incluye también a Jean-Yves Durant, quien leyó un primer bosquejo, y a Pedro Tomé que me ha permitido desarrollar el argumento que aquí presento.

${ }^{2}$ Lo que ha dejado su huella en la toponimia peninsular: la voz CALDAS se utiliza para los baños calientes, así como CALDELAS, BAÑUELOS, BALNEARIO. FUENTE es la toponimia más numerosa (Fuencaliente, Fuensanta, Fuente de la Salud, Fuente Amarga, Fuente de Piedra, Fuente Ferreira) y también POZO, POZUELO. ALHAMA, ALHAMBRA, ALHANUTH, BAÑOLAS, BAÑOS, SANTA MARÍA DE LOS BAÑOS, CALDETAS. Son numerosas las alusiones a imágenes divinas relacionadas con baños o fuentes (López de Azcona, 1966). Sobre el tema del agua, véase Valencia 2006.
} 
posterior oposición enfrentará el agua caliente y fría. Como ha indicado Vigarello, el agua es un medio sutil, pero además tiene un significado social: los que se entregan a los calores del agua no son los mismos que los que descubrirán las virtudes del frío unos años más tarde. Un lujo, una práctica refinada y lasciva se opone a una práctica austera y ascética. El agua fría seduce a una nueva categoría de rebeldes, los higienistas ${ }^{3}$, que plantean una ruptura de la tradición terapéutica. La imagen estereotipada es que "el baño frío, por la condensación de los sólidos da energía y fortifica" (Vigarello 1985:151). El agua fría endurece moral y físicamente. Por ello los antiguos romanos al bañarse en agua caliente se hicieron esclavos, o los salvajes actuales, "ejemplo de costumbres rudas y robustez física" toman baños fríos. Es decir se opone el ciudadano antiguo frente a la víctima del despotismo, las costumbres sencillas contra la corrupción, la regeneración contra la decadencia, la aristocracia a la burguesía. Las prácticas cálidas llevan a la debilidad. "Una nueva clase inventa una nueva fuerza frente a los modelos aristocráticos. Y lo hace reactivando energías y dinamismos, dando solideces y trazando grandes diferencias entre un ascetismo inédito y aparentes indolencias" (Vigarello 1985:155). El frío no es más que un índice en un vasto desplazamiento de valores, la transformación de las referencias sociales. La burguesía ilustrada impulsa imágenes de resistencia y robustez, plantea una imagen nueva del cuerpo y un desplazamiento social, confía en la fuerza del cuerpo, sus vigores, su trabajo, un autofortalecimiento que provoca el frío. A mediados del siglo xIx, el calor y el frío se escinden: el calor sirve para limpiar, el frío para estimular y tonificar. La idea de limpieza gana terreno. Pero con la generalización del baño hay otros temores: el cuidado de la cabeza, los malos pensamientos...se crean baños y lavaderos públicos para corregir las suciedades indigentes y regenerarlas. Con Pasteur los baños se considerarán los mejores desinfectantes.

Y aquí comienza una nueva revolución: el uso del agua en la vida cotidiana. Como ha indicado Goubert: "La leçon de catéchisme [...] pour la remplacer par des leçons d'hygiène" (1996: 153), el agua como medio privilegiado de limpiar, curar, purificar los cuerpos fatigados por el trabajo que engendra la primera revolución industrial. El agua modifica nuestra "civilización material", cambia nuestros gestos, nuestros objetos, el saber científi-

${ }^{3}$ El Higienismo es una tendencia desarrollada por diversos médicos desde fines del XVIII otorgando una gran influencia e importancia al entorno social y ambiental en la génesis y evolución de las enfermedades. En la Ilustración se empieza a estudiar científicamente la curación por medio de aguas minerales como una rama de la medicina, analizando químicamente las aguas. Los escritos médicos en Europa y las medidas que toma el Estado sirven de propaganda en la aristocracia y la burguesía, las primeras en tomar las aguas (o baños de ola) para sanar o fortalecer su salud. 
co, nuestras prácticas tecnológicas, la urbanización galopante, un nuevo orden del mundo que ataca el código social de la propiedad, las viejas fiestas, el gusto del agua en el culto católico ${ }^{4}$. Durante el siglo xIx el culto del agua se hace laico, se higieniza y se impregna de lo cotidiano. En la segunda mitad del siglo aparece un nuevo mercado que tiene que ver con la higiene, el agua, la salud, la toilette: la industria del medicamento, el agua de colonia, la estética corporal. Estamos en la Belle Epoque, con su creencia en la ciencia, en el progreso, en la posibilidad de domesticar la higiene y la salud del cuerpo. El modelo cultural, técnico, económico proviene de las elites. El agua no es solamente objeto de saber científico y técnico, producido por una gran negocio capitalista, es un soporte de las creencias, de los sueños y fantasmas. En la actualidad, a pesar de su valor laico en occidente, el culto de las aguas permanece a través del discurso científico y especialmente el discurso médico, sustituyendo las "aguas santas" por la "higiene sacrosanta" originando la producción de nuevos objetos (bidés, bañeras) y nuevos productos (gel, champú, cremas) (Quintela 1999).

\section{BALNEARIOS: ENTRE LA CURACIÓN Y LA VACACIÓN}

no ay que admirar que con la naturaleza de Cielo, obren los baños en nuestros cuerpos lo que no podemos alcanzar con los remedios regulares, y con un modo no sujeto a los sentidos, sino a la razón, y a la experiencia que obra [...] no tenemos que extrañarnos de que con los baños se curen todas las enfermedades [...] el que usa de las aguas, que hallará un renuevo de vida en si (Martínez de Zalduendo 1699: 28).

Fuentes antiguas e poços antiguos sean de conceyo, e non los cierre nadie ( $E l$ Fuero de Ledesma: "De las fuentes antiguas").

\footnotetext{
${ }^{4}$ Según Goubert el agua tiene 3 edades. La primera edad es de orden cosmológico, la del guerrero, el santo y el hechicero en la que se celebra el culto de las aguas mágicas, sagradas, religiosas. La segunda es una edad religiosa en occidente, la de la cristiandad dominante, donde el agua bautismal lava el cuerpo del pecador. El contacto del cuerpo desnudo con el elemento primordial está prohibido. La tercera edad comienza hacia 1900 en que vuelve el paganismo a la buena sociedad y el burgués se baña desnudo en su bañera de un modo pudibundo. Tiene relación con la ideología de la Revolución francesa por cuanto se llega a explicaciones humanas, racionales y científicas del mundo. El agua se convierte en materia de químicos, geólogos, hidrólogos, físicos y el de los nuevos clérigos: médicos, profesores, ingenieros, hasta llegar a la educación por la salud. Las tres etapas coexisten hoy día y son maneras de concebir el agua, la higiene y la salud (1996:153).
} 
El termalismo está estrechamente unido a los orígenes del turismo tal como han destacado distintos autores (Boyer 1996, Jarrassé 2002, Larrinaga 2002)5. Ir al balneario tiene carácter de viaje y de veraneo a la vez, dos componentes esenciales del turismo. Sus antecedentes son las peregrinaciones (a antiguos santuarios o fuentes cristianizadas), el grand tour inglés en busca de curiosidades (Towner 1985) o los desplazamientos estacionales de los soberanos desde el siglo XVI a los que seguían los aristócratas. Los establecimientos más tempranos aparecen ya en el siglo XVIII en Inglaterra y centroeuropa (la estación de Bath o Spa a la que seguirán Marienbad, Montecatini, Kissingen, Vichy...) (Boyer 1996) y son los lugares de montaña, con una nueva sensibilidad romántica y un marco pintoresco, los que suscitan en Europa un mayor entusiasmo turístico. De hecho, el termalismo es un factor de descubrimiento del territorio nacional, el gusto por la montaña. De aquí surgirán los primeros montañeros y la práctica del esquí en los Alpes o Pirineos. En una primera etapa los pintores se instalan en lugares termales para descubrir paisajes pintorescos, dentro de los ideales románticos del retorno a la naturaleza y la búsqueda de marcos salvajes e insólitos. En este contexto, las aguas calientes, de cualidades telúricas, evocan ecos primitivos del comienzo de la humanidad. La excursión se convertirá en una actividad termal tanto del agüista como del turista ${ }^{6}$. Las guías de los balnearios señalan cascadas, bosques, ruinas o abadías, unidos por una red de

\footnotetext{
${ }^{5}$ El estudio de las aguas medicinales ha sido terreno clásico de la medicina en el campo de la hidrología médica y la terapia hidrológica. Ha habido sin embargo diversos historiadores que han estudiado las termas como destino vacacional como André Rauch (1996) o Armand Wallon (1981) y Douglas Mackman (1998) que han analizado respectivamente la vida cotidiana de las termas en Francia entre 1850-1914 y la asistencia a los balnearios franceses del siglo XIX como una nueva práctica vacacional de la burguesía. Philys Hemphry $(1990,1997)$ ha realizado una historia social de las termas inglesas. Claudino Ferreira (1994, 1995) ha estudiado el termalismo portugués desde la sociología a través de las termas de Curia y Quintela desde la antropología en las termas de San Pedro do Sul y posteriormente en Brasil (2003, 2004).La revista Etnográfica dedicó un número a los usos sociales del agua (2003). En España véanse los trabajos de Montserrat (1995, 1998, 2001), Leboreiro (1991, 1994, 1996), quien ha trabajado sobre la arquitectura y el urbanismo balnearios (Leboreiro 1994, Caz 2000) y los balnearios decimonónicos (Caz y Saravia 1993, Leboreiro 1996). Documentos históricos sobre el balneario de Ledesma son Colmenero (1697), Torres Villarroel (1752) Salgado (1753) García López (1884) y sobre Arnedillo, Martínez de Zalduendo (1699) y Perucho (1972).

${ }^{6}$ La dimensión turística de la estación termal se aprecia en que no todos los turistas son agüistas. Por ejemplo, Baden-Baden en 1870 contaba con 56.000 turistas frente a 6.000 agüistas (Jarrassé 2002). En otros casos se supone que son concretamente los acompañantes los que se dedican más al ocio, o al menos su entretenimiento sirve de coartada para el disfrute de todos. Algo similar señala Ferreira (1995) en las termas de Curia (Portugal) donde son mayoría los "veraneantes" frente a los "aguistas".
} 
caminos, que se inmortalizan en numerosas postales y litografías. Estas guías muestran la ausencia de distinción entre consejos médicos, resúmenes históricos, recomendaciones a los excursionistas y literatura (Jarrassé 2002).

En una segunda etapa, desde la segunda mitad del siglo XIX el balneario depende menos de la naturaleza y se repliega más en sí mismo, en su parque, casino, hoteles. Las ciudades termales se convierten en centros cosmopolitas, los salones de Europa, con pabellones y grandes galerías de hierro y vidrio (trinkhalle). Se crea una red de ciudades de aguas (villes d'eaux), con estancias de dos o tres semanas, unidas a los baños de mar y a las estaciones de invierno. Sin embargo coexisten dos tipos de estaciones termales: las pequeñas, donde predomina la actividad médica, y las grandes o villes d'eaux que ponen más énfasis en el ocio que en la salud. Ejemplo de estas últimas es Wiesbanden que cuenta con ruinas romanas, castillos, monumentos, teatro, casino, parque y un festival de música o Baden-Baden, famosa por sus carreras y teatro (Jarrassé 2002).

El balneario cubre las tres funciones básicas de curar, albergar y holgar. Adquieren importancia el placer y la diversión, el veraneo y el hotel de vacaciones, y supone una evasión de la ciudad y de las exigencias de la vida cotidiana, el retorno a la naturaleza, y el reencuentro con el agua como regeneración. Se trata de un lugar de encuentro propiciado por el propio ritual termal, un espacio de sociabilidad antes reservado a la nobleza del que se apropia con rotundidad la burguesía (Leboreiro 1991, Caz 2000). La asistencia a los balnearios se considera una prestigiosa costumbre social, una práctica elegante y de buen gusto. Los entornos termales, a través de un conjunto de representaciones espaciales, proyectan una imagen de la estructura social donde quedan patentes los intereses de los grupos dominantes. Hay una planificación y construcción del paisaje cuyos enclaves se embellecen con paseos, jardines, arboledas, miradores, pérgolas y terrazas, lagos y cascadas. La naturaleza se domestica para los rituales del ocio burgués y ello se refleja en las tarjetas postales (Gil de Arriba 2000). La estancia termal supone un tiempo vacío que hay que llenar, para curar, retener y atraer. Se construye intelectualmente una ciudad de reposo (y placer) por lo que se asumen una serie de referencias extraídas de la vida urbana, que juegan con el retorno a un estadio ideal y pasado de vuelta a la naturaleza, de belleza, serenidad y utopía. Aparte de la propia regeneración de los cuerpos, el balneario incluye en su nueva concepción y arquitectura el concepto de regeneración del antiguo santuario, con la recuperación, nostalgia y renacimiento de viejos modelos. Muchas de las instalaciones construidas en este tiempo tienen reminiscencias clásicas, romanas o árabes.

Las aguas se revelarán también como un factor de desarrollo local y provincial puesto que una buena parte de las estructuras de acogida, de 
embellecimiento y sociabilidad tiene su justificación en la presencia de turistas o agüistas que buscan aprovechar los placeres de una estación termal. En Europa los extranjeros, atraídos por la fama de algunas estaciones termales, llegan a regiones aisladas lo que provoca un desarrollo económico y cultural además de cierta folklorización de los autóctonos. Se busca lo pintoresco, ya sean las artesanías e industrias locales, el embotellamiento de agua y jabones o las salidas comerciales de productos locales. Un factor importante a este respecto es el paralelo desarrollo de las comunicaciones y el ferrocarril que o bien se activan por la situación de los balnearios o provocan la creación o reforma de éstos (Jarrassé 2002). Y otra característica fundamental es la propia situación urbana; la práctica de los baños y el refugio de la naturaleza se produce al alterarse el equilibrio campo-ciudad con el crecimiento de las ciudades. El balneario se convierte así en un espacio de trasgresión del orden urbano y acercamiento íntimo con el campo y el paisaje: la ilusión de un regreso a la naturaleza cuando ésta ya ha dejado de ser "natural".

Pero no se puede olvidar la dimensión curativa, Alain Corbin (1988) ha analizado la "invención" romántica de la enfermedad como excusa burguesa para llevar a cabo ciertas prácticas de ocio y soslayar así las obligaciones cotidianas entre los que ostentan una fuerte ética del trabajo. A finales del XIX existen dos discursos paralelos: variaciones del veraneo y el ocio con connotaciones frívolas y mundanas y reafirmación de la dimensión higienista. El cuestionamiento de esta última posición y la crítica del factor turístico y mundano influye en la desaparición del termalismo en algunos países como Inglaterra, con la aparición de una agresiva medicalización, que conducirá a un empobrecimiento del sector. La elevada mortalidad de la fiebre amarilla y el cólera demostró que las medidas profilácticas no eran tan eficaces frente a la enfermedad como se pensaba, por lo que se abandonó la pretensión terapéutica a favor del más lúdico y vacacional baño de mar.

Al contrario de otros centros europeos, en España y Portugal no surgen grandes ciudades balnearias ni hay afluencia de visitantes extranjeros. Su auge será más modesto y bastante posterior a Inglaterra y centroeuropa. Los baños de mar por ejemplo comenzarán un siglo después que en Inglaterra. Antes del siglo XVIII los baños termales eran considerados un pecado, un ataque a la religión y a la moral. Aunque a mediados del siglo XVIII las aguas empiezan a ser objeto de atención y hay varias fuentes conocidas (Solán de Cabras, Sacedón, Trillo, Marmolejo, Puente Viesgo...) que utilizan vecinos y comarcanos es en la Ilustración donde surge la primera estación termal planificada - Trillo — creada por Carlos III y la primera villa termal, La Isabela, que se funda en 1817, en ambos casos por iniciativa real (Aguado 2002). Fernando VII acude a los baños de Arnedillo, donde por cierto sufre cierto 
percance (Perucho 1972), e Isabel II a Alhama de Aragón. Los aristócratas primero y los burgueses después ponen de moda tomar las aguas y se hacen cargo de las instalaciones puesto que la modificación artificiosa de la naturaleza y la construcción y remodelación de parque, casino, capilla, establecimiento termal, y gran hotel precisan de un promotor con capacidad de inversión suficiente ${ }^{7}$. Con el fin de rentabilizar la inversión se crean plantas embotelladoras de aguas termales, lujosos casinos (Alhama de Aragón, Archena, Fortuna...) con juegos de azar y salones de baile que frecuenta lo más granado de la sociedad de su tiempo.

La moda de tomar las aguas pues hunde sus raíces en la Ilustración y durante el siglo XIX se ponen en funcionamiento los balnearios, recuperando antiguas instalaciones termales y naciendo otras nuevas. Su mayor impacto tiene lugar en los años del cambio de siglo, y especialmente entre 1860 y 1914, si bien en caso español se prolonga hasta la Guerra Civil. Durante este tiempo se crea un espacio con un modo de vida integral, siguiendo el modelo francés o centroeuropeo. Son pequeñas villas termales, mundos cerrados y completos, que oscilan con mayor o menor énfasis en la curación o el placer, un fenómeno ligado al ocio ciudadano. Aparece vinculado a los cambios derivados de la Revolución Industrial, el desarrollo de la hidrología Médica y el higienismo, los avances de la química, la transformación de la ciudad, la aparición del ferrocarril, el auge de la burguesía y su imitación de las modas aristocráticas, la utilización mercantil del ocio y la salud y el nacimiento del turismo (Montserrat, 2001). Además el auge de los balnearios se debe a la falta de remedios para curar ciertas dolencias y especialmente las enfermedades crónicas. Estos enclaves son una alternativa a la ciudad industrial ${ }^{8}$, una búsqueda de clima y paisaje, lugares de descanso, pero con formas de vida, comodidades y costumbres urbanas. Al balneario acude toda la familia o al menos algún acompañante del termalista al que, en teoría, van dirigidas las actividades recreativas, pero a todos beneficia un "cambio de aires". Esto implicaba un viaje para los más prósperos (ciudad-campo por ejemplo) o un cambio de costumbres dependiendo

\footnotetext{
${ }^{7}$ Uno de estos primeros capitalistas es Nicolás Guillart que invierte en Panticosa en 1826, o Matheu en Termas Pallarés en Alhama de Aragón (Leboreiro 1991).

${ }^{8}$ La población española crece considerablemente a lo largo del siglo: en el año 1800, hay 11 millones de habitantes; en 190018.6 millones (por desaparición de la peste, crecimiento de superficie cultivada y consumo de maíz y patata). Las ciudades se saturan y son insalubres —en Madrid por ejemplo se duplica la población- lo que provoca la creación de ensanches. En el contexto de las ideas higienistas, las capas altas de la población demandan servicios turísticos, aguas termales y marinas en especial. Se busca respirar aire fresco, el poder reparador de las aguas y evitar el aire viciado o el calor de las ciudades (Larrinaga 2002).
} 
de su modo de vida: reposo para los excesivamente activos, agitación para los que viven en el tedio, además de los aires, aguas y alimentos de la "naturaleza", el clima y la montaña como tratamientos de distintas enfermedades. Las termas se presentan como estancias climáticas, lugares de la naturaleza, el epitome de la naturaleza curativa, un sanatorio de la naturaleza (Quintela 1999) en un momento en que la enfermedad preocupa y causa bastante mortalidad.

No solo hay más balnearios sino que mejoran mucho las instalaciones, especialmente en algunos, aunque también hay muchos modestos y baratos. En estos últimos prima la idea de ser alivio de achaques. Dentro de la clientela balnearia, por obligación legal, entre un 10 o un 15\% son enfermos pobres y tropa que reciben los servicios de forma gratuita pero separados de los clientes más acomodados o en establecimientos muy precarios. Deben contar con prescripción facultativa y con un comprobante de su situación social. En este caso los desplazamientos estuvieron claramente motivados por salud y no por ocio o diversión como entre los burgueses. Detrás hay un cambio entre las primeras concepciones médicas de tipo geo-climático a consideraciones socio-urbanas preocupadas por las condiciones de salubridad de las poblaciones (superpoblación de algunos barrios, deficiencias de la vivienda obrera, imperfecciones de alcantarillado y suministro de aguas potables) en relación con la proliferación de enfermedades infecciosas (Gil de Arriba 2000). El último cuarto del siglo ya está extendido el modelo higienista, incluso entre los pobres.

Los balnearios se reglamentan por el Estado desde muy temprano. En 1817 aparece el primer Reglamento de Aguas y Baños Minerales que regula el control médico, mediante la figura de un Director Facultativo en cada balneario9; este reglamento será modificado en 1828 y 1834, fecha en que se crea el Cuerpo de Directores Médicos. En 1874 se establece la necesidad de Declaración de Utilidad Pública para abrir un balneario. En 1877 había registradas 1.865 fuentes en la nación, de las que 188 en 1889 contaban con un médico director (85 en 1851) (Larrinaga 2002). Estas disposiciones legales crearon mucho malestar entre los propietarios de instalaciones termales que habían adquirido las fuentes, en muchos casos procedentes de la Desamortización, y habían invertido en nuevas instalaciones o desarrollo de las existentes. Por ejemplo, en 1869 el Marqués de Santa Marta, José Gutiérrez

\footnotetext{
${ }^{9}$ Probablemente, tal como indica Perucho (1972:32), el propio rey Fernando VII en 1816 decidió la creación del Cuerpo de Médicos Directores de Baños (a los que hacía responsables de aguas y lodos) a raíz del accidente que tuvo en Arnedillo, donde fue a curar los dolores de una pierna, al resbalar en sus lodos con el riesgo de ser tragado por un volcán de lodos.
} 
de Ceballos, Manuel Matheu y otros realizan una Exposición que los propietarios de baños de aguas minerales dirigen al Excmo. Sr. Ministro de Gobernación proponiendo bases para la reforma del derecho balear, a la que seguirán otros documentos (Propietarios 1869, Junta Directiva 1874, Junta Directiva 1910). En ellos reiteradamente protestan del Reglamento de 28 de mayo de 1817 por el que se instaura la figura de un director facultativo, médico de baños, que los propietarios consideran una intolerable ingerencia del Estado en la propiedad de los balnearios, y también por la obligación de proporcionar unas adecuadas estancias para dichos médicos. Solicitan que se les sustituya por inspectores de baños y que ellos puedan elegir libremente médico. Protestan también por la obligación que tienen de dar servicio gratuito a pobres de solemnidad y tropa, además de destinar una habitación a hospital de pobres ${ }^{10}$. Los documentos son una reivindicación liberal de la "sagrada" propiedad frente a ciertas sospechosas tendencias socialistas y comunistas. Pero también aparece aquí una perseverante pugna por el poder entre los promotores y propietarios por un lado y la vertiente lúdica del balneario y por otro los médicos y su énfasis en la terapia y la práctica de la salud.

Los propietarios sin embargo fueron los que tomaron el relevo de las modestas casas de baños y los responsables de estas grandes construcciones de finales de siglo con parque, jardines, Gran Hotel, capilla, casino y teatro. Esta etapa de esplendor se mantuvo hasta la guerra civil cuando bastantes balnearios pasaron a ser utilizados como sanatorios, cuarteles o cárceles. Al igual que en el resto de Europa, aunque un poco más tarde, puesto que la moderna farmacopea tardó más en llegar, el paradigma higienista entró en crisis. El balneario fue perdiendo terreno a favor de la moda de los baños de mar y al divorcio entre terapia y placer: se crearon nuevos procesos terapéuticos como la terapia química y nuevos destinos turísticos como el sol y la playa. La villa termal tenía en su génesis la voluntad de acometer la construcción de un paisaje para atender a las demandas de curación, albergue y ocio de sus usuarios por lo que, al desaparecer ese usuario, languideció. En este último proceso los urbanos pobres y campesinos tendieron a sustituir a los burgueses y también los viejos a los jóvenes.

${ }^{10}$ A este respecto los propietarios señalan las pésimas condiciones en que se proporciona este servicio a fin de que lo supriman: "no puede continuar el envío de dichas clases [tropa y pobres] como boy se hace a los miserables edificios designados con el nombre de cuarteles en algunas de nuestras estaciones balnearias, donde viven hacinados $y$ mal preservados de las impresiones atmosféricas... comiendo sin orden en figones y tabernas..." (Junta Directiva 1874:46). La pugna entre la propiedad balnearia y el estamento médico continuará en el siglo xx. Véase Rodríguez Revilla (1932) y Rodríguez Sánchez (1998). 
A partir de entonces hay una declive de la actividad termal y empiezan a desaparecer las, en su tiempo, lujosas instalaciones por ruina o abandono. Hasta hace poco, y a excepción de unos pocos balnearios (elitistas y costosos), prácticamente casi todos sus usuarios fueron los beneficiarios del IMSERSO. Un inventario de 1992 por la Dirección General de Arquitectura del MOPU puso de manifiesto el deterioro, envejecimiento y obsolescencia de tales balnearios ocupados por las clases populares con programas de servicios sociales.

El sector termal ha resurgido con fuerza en los últimos años gracias a un turismo alternativo de ocio, relax, salud y belleza dirigido a otras clases y edades, un retorno a la medicina natural, global y preventiva, un nuevo enfoque y tratamientos (anti-stress o adelgazamiento). Lo que ofrece un balneario a través del agua termal se considera algo único y exclusivo que no se puede obtener en centros médicos habituales e incluye tratamientos para prevenir disfunciones, reparación y rehabilitación (dietas, relajación, ejercicio, puesta a punto...). Hoy se ha revitalizado entre las nuevas clases medias, que consideran estos espacios menos masificados y más intimistas que el más típico y tópico turismo de masas, lo que ha supuesto una renovación de la clientela y una utilización lúdica del balneario. Se ha creado un Programa de Balnearios, con cargo al 1\% Cultural para la revitalización y mejora de estos establecimientos (Burdalo 2003). El desarrollo del turismo y los cambios en la concepción del ocio, descanso, bienestar físico y psíquico, búsqueda del pasado, lo exótico y el encanto de una cierta decadencia se encuentra en algunos balnearios y esencialmente el valor actual sobre el cuerpo y la apariencia. Hoy tiene futuro dependiendo de su oferta optando por un modelo de seguridad social, turismo de elite o recreativo $^{11}$.

Voy a describir brevemente estas tres posibilidades a través de las investigaciones realizadas en dos termas portuguesas y dos españolas. Se trata del trabajo de una antropóloga, María Manuel Quintela sobre las termas de San Pedro do Sul (Quintela, 1999) y también de la investigación de un sociólogo, Claudino Ferreira, sobre las termas de Curia (Ferreira, 1995) am-

${ }^{11}$ Las fronteras entre uno y otro modelo no están muy claras, dependiendo del tipo de agua que utilizan (por ejemplo la talasoterapia, el agua del mar, o la del grifo en los más recientes "balnearios urbanos", los circuitos acuáticos de algunos hoteles, etc.). Aquí me refiero fundamentalmente a los establecimientos de agua termal. Las guías de balnearios no se ponen de acuerdo en qué se considera un balneario y por tanto en cuanto al número de balnearios existentes. La Guía oficial de Balnearios de 1994 listaba 81 pero según Vila, en 1995 había 128 balnearios. Balneario no equivale a fuente termal, de las que existen unas 2000 en España. 
bas en Portugal ${ }^{12}$. Por último me referiré al Balneario de Ledesma (Salamanca) y al Hotel-Spa de Arnedillo (Logroño) dentro de mi propia investigación ${ }^{13}$.

\section{II.1. San Pedro do Sul: un buen lugar para envejecer}

Quintela ha señalado cómo ya desde el siglo XIX la inquietud por la enfermedad se transfiere a la preocupación por la salud y su prevención. Aunque este desplazamiento refleja que la enfermedad se ha convertido en algo poco estético en la cultura de consumo (Featherstone 1991) el balneario logra unir "Curar e folgar", (el significativo título de su trabajo) por lo que se plantean una serie de ambigüedades: ¿cómo una práctica terapéutica origina la construcción de un lugar turístico? ¿Dónde empieza el enfermo y acaba el turista? Las Termas de San Pedro do Sul se decantan hacia la curación. En la perspectiva de la población local las termas son un lugar terapéutico organizado para las necesidades de los dolientes (reposo, silencio, descanso, sosiego) aunque en otros lugares de la localidad se mezclan sin conflicto terapia y recreación. La paradoja es que ambas se consideran importantes para curar. Todo lugar termal es as la vez hotel y hospital y tiene características comunes. Y la población local no solo no evita a los enfermos sino que trata de atraer un nuevo público por su propia supervivencia económica y la de la localidad. En 1997 el 80 \% de los "aguistas" de San Pedro eran reumáticos, según su Informe Clínico, y de cierta edad. En sus conclusiones Quintela afirma que la práctica termal se caracteriza por la búsqueda de tratamiento, es un período de relación privilegiada con el cuerpo, donde se replantea la existencia en relación con el sufrimiento y lo lúdico. Además el termalismo supone un periodo de inversión y suspensión de lo cotidiano, una mudanza de aires, pero también un lugar donde ser viejo es bueno, un buen lugar para envejecer, donde lo lúdico toma el lugar del sufrimiento y el dolor pero también un lugar donde la dolencia y el cuerpo tienen su lugar y no son perturbadores. Los trabajadores rurales lo justifican como un descanso necesario con fines terapéuticos, los ciudadanos "cargan baterías" y para algunos grupos sociales esta es la posibilidad única de vacaciones, puesto que la enfermedad es la única legitimación de descanso.

${ }^{12}$ En ambos casos se trata de Tesis de Mestrado (Ferreira 1994, Quintela 1999) que realizan ambos. Las referencias de Quintela son de esta investigación, aunque ha publicado otros trabajos $(2003,2004)$. En cuanto a Ferreira, las referencias aparecen en su excelente artículo de 1995.

${ }^{13}$ He sido usuaria durante varios años del balneario de Arnedillo, si bien ha sido en los 3 últimos años cuando he recogido datos de forma sistemática al igual que en Ledesma al que he acudido en diversos periodos. 


\section{II.2. Curia: entre dos aguas}

Las termas de Curia ofrecen una perspectiva diferente, más volcada hacia el turismo y separada en dos grupos ${ }^{14}$. En las termas se cruzan grupos sociales diferenciados y se confrontan expectativas, motivaciones y estilos de vida heterogéneos basados en la doble faceta del balneario: el turismo y la terapia, atrayendo diferentes clientelas. En Curia coexisten pues dos posturas culturales distintas, una cultura popular con celebración pública de sociabilidad que mezcla lo lúdico y terapéutico y una cultura elitista que se apropia de espacios lúdicos para la celebración de ocios intimistas y distintivos.

Según Ferreira siempre hubo estos dos grupos. Para la clase popular lo lúdico estaba subsumido a lo terapéutico. Para la clase alta la dimensión terapéutica era más un pretexto para un estilo de vida ocioso, lúdico y exclusivo. Si bien el agua había sido utilizada desde mucho tiempo antes por las clases populares, la intervención médica y la presencia y capital de las elites locales arrinconó los saberes populares, marginalizando a los grupos más modestos que, a pesar de ello, siguieron utilizando terapéuticamente las termas (cabinas de $1^{\underline{a}}, 2^{\underline{a}}$ y $3^{\underline{a}}$, alojamiento en pensiones, etc.). La actividad lúdica se agota hacia 1930 por la falta de inversiones frente a otros espacios de vacaciones. Tras la democracia, en 1974 el Estado portugués crea programas de termalismo social para los beneficiarios de la Seguridad Social, como forma de revitalizar la fuerza de trabajo y permitir a las clases populares una temporada de vacaciones. Se produce un incremento masivo de la demanda popular, con población envejecida predominante y con mayor peso de la dimensión terapéutica sobre la lúdica. Hacia 1990 estas termas vuelven a cobrar vida como centros turísticos y en la actualidad se equilibran ambos componentes. Así pues en Curia se dan dos tipos de clientes, los usuarios de las termas, "los aguistas", que son minoría frente a los "veraneantes", estos últimos atraídos por el paisaje y el ambiente social y no tanto por las aguas.

Agüistas y veraneantes se distinguen por la edad, la condición socio-profesional y el nivel de escolaridad. Los aguistas son una población de edad, tienen una media de 60 años y más de la mitad no trabajan (jubilados o amas de casa). Los activos y jubilados provienen de los servicios o industria o pequeños comerciantes, obreros y poco escolarizados. Se trata pues de una población popular cuya estancia en las termas se centra en el agua

\footnotetext{
14 Según Ferreira las vacaciones son momentos de redefinición de identidades, actualización de estilos de vida y renovación de sociabilidades. Viene a ser un ritual de paso pero también una continuidad del status, capacidad económica y preferencias simbólicas de los individuos (Bourdieu 1979). Ferreira define las termas como espacios complejos de vacaciones (Ferreira 1995: 95 y sigs.).
} 
y el reposo; acuden por las virtudes del agua, el ambiente tranquilo y porque se lo manda el medico. Para esta población la dolencia es una parte de sus preocupaciones, sus imaginarios, discursos y representaciones. La vida termal de los agüistas está marcada por la disciplina corporal y la vigilancia permanente del cuerpo doliente y toda su cotidianeidad se construye alrededor del agua que consideran muy medicinal, especialmente en las dolencias crónicas o las originadas por el envejecimiento: es un ritual cíclico de regeneración que tiene que ser repetido anualmente. El uso del espacio y el carácter público del ceremonial balneario provoca una intensa sociabilidad e interacción, donde se comparte achaques, tratamientos, saberes, gestión de tiempos y actividades, charlas, paseos, siestas, cafés. Los agüistas se alojan en pensiones, cuartos y casas particulares. Es una comunidad emocional en torno al cuidado del cuerpo "interior"15. El doble estigma de la dolencia y la vejez, factores de marginalización social en la sociedad actual, (Featherstone y Hepworth 1991) aquí se convierte en una identidad positiva y compartida. La temporada termal es regeneradora no sólo en términos físicos sino psicológicos.

Los veraneantes, de edad media de 46 años, son mayoritariamente profesionales con altos niveles de cualificación, profesiones liberales y niveles de educación elevados. Se trata pues de una clientela joven, nuevas clases medias urbanas, que valoran la tranquilidad y el paisaje especialmente, y también la estética y la relación con la familia. Las termas son estancias cortas que complementan con la playa o vacaciones en otros lugares. La gran mayoría de los veraneantes va a los hoteles en los que buscan contextos de privacidad, intimidad y placeres autocentrados o en círculos restringidos. Frente a los agüistas, los veraneantes tienen una mayor frecuencia de diversiones, mayor movilización de energías físicas (piscina o deportes) e intelectuales (lectura por ejemplo) y más cerradas a los extraños, en el contexto de sus familias. Se valora la tranquilidad y el paisaje y también el poder evocativo de las instalaciones hoteleras clásicas como centro glorioso antiguo, convivencia nostálgica de un estilo de vida y ambiente elitista y mundano, que ejercen un efecto de seducción. Los veraneantes se reconocen como una comunidad efímera que comparte un ambiente estético, sensaciones y un modo de vida.

15 Tal como lo define Featherstone en relación a la cultura de consumo (1991:171) "The emphasis upon body maintenance and appearance... suggests two basic categories: the inner and the outer body. The inner body refers to the concern with the health and optimum functioning of the body which demands maintenance and repair in the face of disease, abuse and deterioration accompanying the aging process. The outer body refers to appearance as well as de movement and control of the body within social space...as well as the aesthetic dimensions of the body". 
En el lujoso Grande Hotel da Curia hay una categoría especial de veraneantes: los "practicantes de la forma física" quienes dedican la temporada termal a una puesta a punto, mantenimiento y modelación del cuerpo "exterior": body building (rehabilitación, sauna, embellecimiento, deporte, régimen dietético, relajamiento, anti-stress...), un vehículo de placer y actuación individual y una estrategia de valoración hedonística del cuerpo, característica de las nuevas clases medias urbanas. Así pues agüistas y veraneantes se agregan en comunidades emocionales y se diferencian entre sí. Muestran la lógica de la diferenciación y la competición de estatus.

\section{II.3. Ledesma: el balneario de los mineros}

El Balneario de Ledesma situado en Vega de Tirados (Salamanca) se encuentra en la margen derecha del río Tormes a unos 9 kilómetros del pueblo de Ledesma. El edificio fue construido sobre unas antiguas termas romanas y sus aguas desde 1886 son de Utilidad Pública. En el siglo XIX tuvo su época de mayor auge con el impulso de la burguesía que construye sus instalaciones, declaradas en 1931 Monumento Histórico-Artístico. Fueron de propiedad privada hasta los años 40 que pasan a ser propiedad estatal y luego de una sociedad mercantil. Desde 1944 hay una cesión de uso a la Caja de Jubilaciones y Subsidios de la Minería Asturiana, antecedente del actual dueño, el Montepio y Mutualidad de la Minería Asturiana ${ }^{16}$. El agua termal se aconseja para el tratamiento y prevención de reumatismo, artrosis, traumatismos, enfermedades de las vías respiratorias, neurológicas y dermatológicas, dolencias de la mina y de lugares húmedos. El hecho de situarse el balneario en un lugar de Castilla, de clima seco, tiene también su importancia ya que se dice los mineros iban allí a "secarse", a pesar de ir a disfrutar de las "aguas".

El edificio actual, construido en 1975 y renovado en 1990, es uno de los mayores complejos balnearios del país, con una gran capacidad ya que puede albergar cerca de 700 plazas en los meses de mayor ocupación (julio y agosto) aunque normalmente lo ocupan unas 500 personas al mismo tiempo $^{17}$. Las instalaciones termales incluyen una piscina exterior que se utiliza en verano, amplios jardines, capilla, un templete de música y una pequeña pista de baile. También cuenta con un café muy concurrido con mesas en el interior y el exterior, salón social, farmacia, peluquería, algu-

${ }^{16}$ Sobre los antecedentes de estas asociaciones, véase la obra de José Luis García García y especialmente su texto sobre prácticas paternalistas (1996: 158 y sigs.)

${ }^{17}$ Cada mes de los que permanece abierto hay más de 1.000 entradas registradas y en algunos meses se llegan a contabilizar 1.500 . 
nas tiendas de prensa y recuerdos y aparcamientos. Las habitaciones del hotel de tres estrellas, más bien austeras, y con cierto olor a desinfectante, incluyen teléfono, televisión y un pequeño frigorífico. En el hall hay un servicio de Internet con varios ordenadores. El balneario permanece abierto de marzo a noviembre; el resto es tiempo que se dedica al cuidado y arreglo de las instalaciones. Hay 3 médicos hidrólogos y unas 125 personas en plantilla (datos 2006).

Pese a estar situado en Castilla, el balneario parece un enclave asturiano ${ }^{18}$. Al balneario llegan autobuses procedentes del Principado con el lema Asturias, paraíso natural que dejan a los recién llegados y se llevan a los que han cumplido su turno rotando cada catorce días. Desde Asturias hay 4 rutas que recoge mucha población de zonas mineras. El Montepío ocupa principalmente el establecimiento en temporada alta (mediados de mayo a mediados de octubre) dejando las otras fechas al IMSERSO, Once o Diputación de Castilla-León.

Hay dos turnos de comidas y cenas y un comedor muy amplio. Organizar la pensión alimenticia de cerca de 500 comensales por supuesto no es tarea fácil y se me dice que "hay que organizarse como en el ejército". Una característica del comedor es que, a diferencia de otros balnearios, nadie come solo ya que los huéspedes deben compartir mesa y se acomoda a los mismos buscando ciertas afinidades de edad u origen favoreciendo su interacción. La sociabilidad se incrementa también por su situación aislada. El balneario, a 9 kilómetros del pueblo que le da nombre, es un enclave natural prácticamente solitario en medio de una dehesa salmantina sin comercios $^{19}$ o bares aparte de los del balneario. Uno de los paseos favoritos es el recorrido a pie de la carretera de acceso al balneario hasta la carretera general, ida y vuelta, que discurre bordeando fincas rurales. Pero también se organizan diversas excursiones a lugares de alrededor (Alba de Tormes, Candelario, La Alberca) siendo la más popular la excursión a Portugal (Miranda do Douro) para realizar compras. Una manera de entender lo que ha significado el balneario para sus usuarios es a través de una curiosa característica. En el balneario, subiendo las escaleras hacia el monte hay varias edificaciones: una pista de baile para el verano, un estanque y en lo alto un depósito de agua y una caseta. Allí hay una buena colección

${ }^{18}$ El hall y el comedor del hotel del Balneario está lleno de motivos del Principado (madreñas, pequeños hórreos, imágenes de la Virgen de Covadonga) y especialmente de la mina (reproducciones de trenes, picos, vagones de carbón diminutos, instrumentos y lámparas de grisú, trofeos con motivos mineros, etc).

19 Aparte de algunos puestos callejeros o furgonetas que se sitúan fuera del recinto donde se venden prendas de vestir, productos de la zona o embutidos. 
de graffitis, pinturas en los muros y algunas poesías. El análisis de los motivos que recogen, que ha sido hechos en diferentes épocas, sirve para entender lo que ha significado el balneario en el pasado ya que contienen valores sobre la estancia en el mismo. Un rasgo común a todos ellos es que las huellas pictóricas y poéticas se refieren a Asturias y más concretamente a la mina ${ }^{20}$. Pero además varios de los escritos se refieren al balneario como lugar donde convergen las distintas clases sociales y al trato igualitario que su personal proporciona a todos:

De toda la servidumbre estamos agradecidos y los elogios que hagamos los tienen bien merecidos. Porque aquí viene de todo, pobre, rico, guapo y feo, bueno, malo, sano, enfermo, servil, cristiano y ateo pero aquí no hay diferencia y todos somos igual en la mesa y en la cama, hasta en el trato social, ahora por si volviere con el corazón...

(Jesús Vázquez de Paxio) ${ }^{21}$

Esta otra poesía recoge la experiencia balnearia con nostalgia: desde la excursión previa a Covadonga antes de llegar hasta la despedida pasando por referencias a los empleados, la cocina, las instalaciones y tratamientos. También indica la clase de usuarios del balneario:

\section{El Balneario}

Ya llegué, ya estoy aquí, ya visité a la Santina, la más grande de mi Asturias y la llamamos pequeñina. Ya conocí el personal que cuida su mantenimiento, ya veré yo si en mi casa puedo seguir este ejemplo. Ya paseé hasta la fuente entre la gente de mi tierra, gente que viene del campo y de la cuenca minera. Ya conocí al cocinero, maldigo esta buena hora pues cuando yo llegue a mi casa, pobre de mis cacerolas.

${ }^{20}$ Un cuadro pintado por Luis G. Requejo en el año 1977 contiene dos balagares, un paisano llevando dos vacas, un prado, montañas, un caserío y en primera línea un hórreo. Hay vacas pastando y a la izquierda un gaitero tocando la gaita debajo de un árbol. Como es obvio se trata de un paisaje típicamente asturiano, con todas sus características tópicas. Una leyenda abajo dice: "Dedicado a la simpatía del personal del balneario". Al lado hay otro cuadro del mismo autor que dice "Dedicado a los mineros de toda Asturias" con una columna que corona una Virgen de Covadonga; el pintor dejó además una poesía. Este motivo de recuerdo y exaltación de la tierra asturiana se repite en bastantes de los grafittis de diferentes épocas. Por lo que indican las poesías, parece que la asistencia al balneario incluía una visita al Santuario de Covadonga.

${ }^{21}$ Del mismo tipo es una prosa que se dedica concretamente a las empleadas del balneario, titulada: "A vosotras chicas del balneario". 
Ya hice las inhalaciones, los baños y las estufas aquí se quedan mis dolores y yo me marcho a mi Asturias.

Ya me cogieron en el cuello como si fuera de rollo ya me pasearon en silla como si fuera un retoño. Ya recorrí el balneario desde el sótano hasta el techo, ya se ve que el direztor quiere conservar su puesto. Ya me voy para mi Asturias, saludando con la mano, no quiero decir adiós, quiero volver a otro año.

(Una riosana, 1988)

Otro poema se refiere al aspecto terapéutico del balneario que hace el milagro, junto con la Santina, de "resucitar" a la paciente. Obsérvese la sociabilidad que se destaca en la poesía ${ }^{22}$ :

\section{El balneario}

Estoy contenta de acudir a las estufas y baños tenía la muerte anunciada y ahora voy a durar años. gracias al balneario y a la Virgen pequeñina que la conocí este año.

Comemos cuatro a la mesa, compañeros de trabajo, estamos aquí como si fuéramos hermanos, estamos pidiendo a Dios poder volver otro año contentos con las mocinas que nos asistieron este año que lo disfrutan muy bien todos los del balneario...

(Rosalina y Emilia de Laviana en 1990)

Pero quizá la poesía más impactante es la que sigue, que evoca la desesperanza de la silicosis, la temible enfermedad profesional del minero que, en el pasado, motivó probablemente su visita al balneario, tal como se indica aquí:

${ }^{22}$ En el pasado, para diversas personas, la estancia en el balneario debió de ser la única ocasión de disfrutar de unas vacaciones, tal como se sugiere aquí:

Por primera vez venimos/ y con ganas de volver a los baños de Ledesma/ que bien nos han de hacer, con nostalgia nos marchamos/ y contentos a la vez por los compañeros/ y las juergas que montamos y lo bien que lo pasamos. (Ros mel clar Laviana 7-8-05).

Algunos graffitis son humorísticos, como estos que siguen:

Somos tres amigas, /que venimos de Xixón, que será nuestra afición/ que venimos a echar un chinchón.

Cojo vine/ cojo marcho

Pero con el corazón abierto

Para otro año. 


\section{Dos silicosos}

Hablando casi sin voz / despacito poco a poco llegaron hasta ese banco. / Y uno le dijo al otro: "No nos vamos a curar / si no inbentan algo y pronto" El otro le contestó: / "Te voy a ser muy sincero, ni con agua disolvente,/ ni con cepillo de acero, ni con estufas ni baños, /ni inhalaciones por dentro pude quitar esa costra/ que me atenaza hace tiempo, y si hago más me mato /y si no lo hago me muero".

(Una riosana)

En un tono menos amargo este otro poema se refiere a los males producidos por el clima y la dedicación a la mina en las zonas asturianas:

\section{Los mineros}

Aquí están los asturianos / que venimos a curarnos del mal que nos persigue / casi todo el año, el lombago, el reuma, /la silicosis, la artrosis, el asma y algo más / son los males más frecuentes que nos atacan allá.

Con los baños, les estufes / inalaciones y de más seguro que nos curamos / y oi ya lo verás.

Trátanos tratan muy bien / casi todo el personal y no nos apetece marchar.

(1990 Firma ilegible).

Las poesías destacan varios aspectos. En primer lugar, las continuas referencias a Asturias en territorio castellano sugieren que los autores no están muy acostumbrados a salir fuera del Principado y ciertos párrafos atestiguan este punto ("Por primera vez venimos/ y con ganas de volver..."). El viaje al balneario es para algunos de los vates algo extraordinario; a ello se unen las diversas y excesivas referencias a la amabilidad de las camareras, la calidad de la comida y el trato recibido que, para alguien más asiduo, no se consideraría tan especial. La estancia en el balneario tiene un componente claro de placer ("las juergas que montamos y lo bien que lo pasamos") pero también y más importante el del alivio de la enfermedad a través de las distintas técnicas y tratamientos, que son minuciosamente destacados. El carbón y la mina y las enfermedades derivadas del modo de vida minero se amplifican de un modo épico. Por el tipo de mensajes los que lo escriben probablemente son: "la gente de mi tierra, gente que viene del campo y de la cuenca minera". Vamos a ver qué tipo de usuarios hay en la actualidad.

Como he indicado, la época de mayor ocupación de Ledesma se produce en julio y agosto y también la de una clientela de menor edad. En general 
la media de edad de los usuarios del balneario es bastante elevada. De los 10.924 usuarios de 2005 casi la mitad provenían del IMSERSO (47\%), seguidos del 42-3\% del Montepío, la Junta de Castilla y León, la Once, privados, etc. ${ }^{23}$. Esta elevada cifra de beneficiarios del IMSERSO se corresponde con la cifra desglosada por edad; tres cuartas partes de los asistentes tienen más de 65 años y un pequeñísimo porcentaje tiene menos de 18 años:

$\begin{array}{lrrr}\text { Menores de } 18 \text { años ..... } & 196 \text { personas ....... } & 1.79 \% \\ \text { Entre 19-64 años .......... } & 2.634 \text { personas ....... } & 24.15 \% \\ \text { Mayores de } 65 \ldots \ldots \ldots \ldots \ldots . . & 8.094 \text { personas ....... } & 74.11 \%\end{array}$

Dentro del paisaje del balneario la presencia de los mayores es obvia, evidente y recurrente. Por la mañana (entre 7-13.30 horas) están enfrascados en los distintos tratamientos según sus dolencias ${ }^{24}$. Durante los meses cálidos los jubilados dan pequeños paseos por el recinto, por la carretera de acceso al balneario al caer la tarde y se sientan en los bancos y las sillas alineadas en la explanada de la cafetería, un lugar con árboles que facilita la comunicación. Muchos se trasladan ayudándose con un bastón y algunos en silla de ruedas. Sin embargo en el balneario se practica una intensa sociabilidad. Se organizan continuamente partidas de naipes, juegan al bingo organizado en el balneario, hacen trabajos manuales y asisten al baile que se organiza los sábados con algunas orquestas locales, música disco o a las reuniones con animadores que amenizan las tardes. Suelen ir a casi todas las excursiones, a pesar de los achaques, y acuden disciplinadamente a las charlas informativas. Un panel de información en la entrada del hotel da cuenta de las actividades programadas día a día. Para los mayores la estancia en el balneario tiene una dimensión terapéutica pero también es un periodo de vacación, y en ocasiones el único de todo el año al que pueden acceder. Dado que los jubilados de la mina llegan desde destinos cercanos muchos se conocen y se saludan de un año para otro pero también se hacen nuevas amistades.

${ }^{23}$ Según me indica el director del Balneario en 2006. Sin embargo en la documentación estadística que me proporciona aparece otra cifra de 11.575 entradas (y 127.747 pernoctaciones). Una cifra de entradas similar se produjo en 2004, con 11.804 en total. En el año 2005, de un total de 11.575 entradas, 4.988 eran asturianos, doblando la cifra de los provenientes de Castilla y León y Madrid respectivamente (2.782 y 2.385). En 2004 fueron 5.204 los asturianos de un total de 11.804 (frente a 2.753 de Castilla y León y 2.393 de Madrid). Especialmente importante es su presencia en julio y agosto (1.018 y 1.371) aunque también acuden en junio y septiembre $(872,878)$.

${ }^{24}$ Entre los tratamientos se encuentran estufas, inhalaciones, duchas nasales, pulverizaciones, baños de inmersión, chorros, duchas circulares, masajes, piscina y gimnasio de rehabilitación, solarium y parafangos, todos ellos tratamientos tradicionales. 
En el cuarto restante, los comprendidos entre 19-64 años se incluyen acompañantes, activos, prejubilados y aquellos jubilados de la mina a los que se aplica un coeficiente reductor ${ }^{25}$. Esta edad se concentra en los meses de verano: en muchos casos la estancia en el balneario no supone la utilización de los servicios de balneroterapia, ni acuden al encuentro informativo sobre los tratamientos que se ofrecen. Únicamente utilizan con asiduidad la piscina exterior, lo que indica que, para este colectivo, el balneario es claramente un lugar de vacaciones, algo que motiva algunas críticas al respecto por parte de la dirección del balneario. Pero además mientras que los jubilados acceden al balneario en autocares o transporte público (o son trasladados por sus familiares) y dirigen su sociabilidad hacia dentro, los usuarios en esta franja de edad se trasladan en coche propio lo que supone una mayor movilidad e independencia. Los prejubilados, jubilados jóvenes y activos que conocí hacían un uso considerable del automóvil para acceder a bares, restaurantes y fiestas de los pueblos cercanos, excursiones a Portugal y otros lugares, dirigiendo pues su sociabilidad hacia fuera. La dirección del balneario me indica "como tienen coche se largan, no participan del balneario". Así pues la asistencia al balneario ha pasado por diversas etapas: lo que era en su origen una práctica terapéutica para los mineros, sus principales usuarios, se convirtió durante años en una temporada vacacional. Con la aparición de dos centros de vacaciones junto al $\operatorname{mar}^{26}$, los principales usuarios actuales son claramente los jubilados de la tercera edad.

En definitiva, la idea de vacaciones que tiene la gente más joven no es precisamente este balneario, un lugar que se considera austero y ascético, aislado, con poco que hacer y apenas sin diversiones. El recinto del balneario se cierra por las noches por lo que no es factible trasnochar. Varios de los prejubilados que conocí consideraban la estancia en el balneario como una cura de reposo, meditación, y relajación aunque por las tardes abandonaban el lugar en coche buscando "chigres" en Castilla. Los prejubilados que vienen son los que necesitan los tratamientos por cuestiones de salud pero así y todo me dicen: "hacen una semana los tratamientos y la otra están de turismo". Sin embargo se repite que en el balneario "hay ambiente de

${ }^{25}$ Coeficiente que oscila entre el 0,50 de muchas de las categorías del interior, entre otras las de picador o barrenista al 0,05 de categorías de exterior (www.mmma.es/seguridad social/coeficientes reductores.htm) Por el primer coeficiente cada año trabajado cuenta como 1.5, lo que supone que el trabajador se puede jubilar (y no prejubilar), por ejemplo, a la edad de 52 años, dependiendo de los años trabajados.

${ }^{26}$ El Complejo Minería Asturiana de los Narejos, un conjunto de chalecitos en Murcia y los Apartamentos Minería, un edificio de nueve plantas en Roquetas de Mar (Almería), ambos propiedad del Montepío. 
jubilados y el ambiente de estos y de los prejubilados no es igual”. El balneario claramente tiene una edad, pero no siempre la misma.

\section{II.4. Arnedillo: el Hotel-SPA}

El balneario de Arnedillo en La Rioja muestra un fuerte contraste con el balneario de los mineros. Sus termas, conocidas por los romanos, fueron administradas por la pequeña villa de Arnedillo hasta 1646 en que pasa al Consejo de Castilla. Volverá a la administración de la villa en 1836 tras sufrir un terremoto en 1817 que destroza parte de sus instalaciones. En 1847 lo compra Florencio Martínez de Pinillos, el primer propietario de una saga familiar que ha continuado hasta la actualidad a través de siete generaciones. En 1995 sus herederos convierten el hotel del balneario en el Hotel Spa y en el 2001 los descendientes de esta familia propietaria crean la cadena de balnearios Terma Europa a partir de la experiencia de Arnedillo ${ }^{27}$.

El Hotel-Spa de cuatro estrellas ${ }^{28}$ tiene acceso directo al balneario y cuenta con 135 cómodas habitaciones redecoradas recientemente. Aparte de otros servicios (cafetería, tiendas, gimnasio, peluquería, capilla, bar al aire libre, pista de tenis, WI-FI, biblioteca) hay varios salones de reposo, dos restaurantes a elegir por los residentes (uno de ellos tipo buffet) y varios menús y posibilidades de elección de extras o comida de picnic. Hay ofertas especiales para empresas y para ello cuenta con distintas salas de reunión de diferentes tamaños. El hotel organiza diversas actividades como clases de yoga, gimnasia,y acuagym, rutas de senderismo mañana y tarde y la visita a una bodega para probar vinos dos veces por semana. Hay dos sesiones de cine al día (tarde y noche) con diferentes películas. Pero además mantiene una guardería y un Club Junior con monitores.

Sus aguas son sedantes, muy recomendadas para el estrés, una de las especialidades de Arnedillo. El tratamiento estrella es el del barro y baño. Los barros son famosos con propiedades antireumáticas y relajantes y se maduran de forma natural. También es característica la Terma Romana, un circuito de piscinas y saunas de distintas temperaturas.

Aunque hay algunos programas terapéuticos de seis días (recuperación, piernas pesadas, escuela espalda, reumatológico, vías respiratorias), sin

${ }^{27}$ Los primeros en entrar al grupo han sido los balnearios Carlos III (en Trillo), Costa Calero (Lanzarote), Coma-ruga (Tarragona), y un balneario urbano en Valencia. Hay prevista la incorporación de otros.

${ }^{28} \mathrm{El}$ complejo de Arnedillo incluye también en su recinto, a unos 300 metros, otro hotel de menor categoría (tres estrellas), El Olivar con 45 habitaciones que utiliza los servicios del restaurante del Spa y sus instalaciones termales. 
embargo los más frecuentes son los programas especializados en combatir el estrés, tratamientos de belleza, puesta a punto y bienestar, de duración menor - en teoría entre dos y cinco días pero más frecuentemente dos o tres días y especialmente los fines de semana- (programas de relax, belleza y bienestar, puesta a punto, distress, vitalidad, belleza integral...) y variedad de masajes y tratamientos de estética (faciales, corporales, pies y manos, depilaciones...). El balneario incluso mantiene una línea de cosmética propia. Sus instalaciones están muy cuidadas e incluyen varias piscinas como el Club Forma (una piscina activa semi-cubierta con chorros, camas de burbujas, jacuzzis), o la más reciente piscina de olas, aparte de otra piscina al aire libre de agua termal abierta todo el año.

Obviamente los tratamientos del balneario, su duración y la época de la semana en que se disfrutan, el carácter de sus instalaciones y servicios sugieren el tipo de establecimiento y clientela de que se trata. Cuando se convierte el hotel en Spa se hace la siguiente apuesta:

además de ser útiles para dolencias y enfermedades, sus características son beneficiosas para una utilización puramente lúdica, buscando diversión y relax al mismo tiempo[...] ponerse en forma, o pasar un rato agradable disfrutando del agua, lo que se viene a denominar la salud por el agua (Guía, s/f)

Esta declaración de principios anuncia los nuevos planteamientos de este balneario, su decantamiento por la dimensión lúdica frente a la terapéutica y su énfasis en la salud frente a la enfermedad. En los fines de semana, puentes y vacaciones especialmente, la edad de la clientela en Arnedillo disminuye drásticamente ${ }^{29}$. Jóvenes parejas, con niños o sin ellos y grupos de ejecutivos estresados forman parte del paisaje balneario. Parece ser que el mayor incremento de huéspedes en Arnedillo se ha producido precisamente en el intervalo de edad entre los 25 y 45 años (Vázquez-Illá s/f). Este dato es significativo ya que en Arnedillo hasta 1990 aproximadamente había sido un establecimiento balneario tradicional con mayoría de la tercera edad y programas sociales. Un documento que aparece en la red escrito por el director del balneario en esa época ${ }^{30}$ es altamente esclarecedor de esta diferencia y además señala el momento concreto de toma de conciencia y cambio de perspectiva. Tras una introducción sobre el concepto de marke-

29 De tal manera que en algunos casos he escuchado, ante el griterío de un buen número de niños corriendo por el hall, la protesta de los huéspedes "Uno viene al balneario a descansar, buscando paz y tranquilidad".

30 (http://aguas.igme.es/igme/publica/pdjfor_aguas_mine16_marketing.pdf.). Se trata del documento titulado "Marketing externo e interno de un balneario" firmado por Javier Vázquez-Illá Navarro, director del Balneario de Arnedillo. No lleva fecha, si bien los programas termales del anexo llevan fecha de 1991-2 por lo que pudo escribirse hacia 1993. 
ting el director se plantea "en qué negocio estamos... en el negocio de los balnearios o en el hotelero" y responde que el negocio es proporcionar lo que el cliente busca en el balneario:

satisfacer una necesidad personal, como puede ser la de descansar o recuperar la forma o sobreponerse o mejorar de una enfermedad o pasar unas vacaciones disfrutando de la naturaleza[...] [el servicio base es] el tratamiento termal enfocado, fundamentalmente, a las personas que padecen enfermedades reumáticas[...] segmento de mercado de la tercera edad [pero el balneario puede también] "ofrecer otros servicios-base derivados como los hoteles, piscinas, baño romano, masajes e instalaciones diversas". (Así) los segmentos de mercado son variados: segmento reumáticos tercera edad, segmento adeptos a programas de puesta en forma ligados a vacaciones activas, segmento reuniones de empresa que buscan oferta de ocio deportivo o salutífero complementario, segmento turistas de vacaciones en la naturaleza.

El problema fundamental con estos segmentos es si son incompatibles entre sí, puesto que ello conlleva serios "peligros", por ejemplo, la pérdida de otro tipo de clientes cuando se trabaja con grupos de IMSERSO, ya que ello supone unos determinados servicios (atención, animación, horarios y clase de comida) que no se comparten por los más jóvenes (o de los que "huyen" los más jóvenes). El balneario intenta mantener un hotel para cada segmento ${ }^{31}$ pero "las disparidades en el tratamiento o en la producción de un servicio para un reumático o un ejecutivo son enormes" y para ello "la consulta médica se hace más light" es decir no es ya una obligación como en el caso de los clientes reumáticos sino tan solo "el médico se transforma en un asesor del enfoque salutífero de las instalaciones" para no perder ninguno de los segmentos. A este fin también se diferencia entre los programas animación para los clientes de más edad (gimnasia, natación, clases de cocina, pastelería o confección de flores) y la gente más joven (senderismo, visitas a la bodega, excursiones). Dirigido a este último "segmento" son los programas para niños y posteriormente la creación de una guardería. En el anexo aparecen varios programas dirigidos a la población activa ("fin de semana en salud" o "fin de semana en salud más curso de cata") ejecutivos ${ }^{32}$ ("reunirse es un premio en salud") o gente en vacaciones 33 ("programa de puesta en forma").

${ }^{31}$ Los dos hoteles del balneario, uno de tres estrellas y otro de cuatro, que se suponía ocupaban los dos segmentos respectivamente, los "reumáticos"(o tercera edad) y "gente sana" (jóvenes). Algo similar sucede en otros balnearios, por ejemplo, Archena también con dos hoteles de distinta categoría.

${ }^{32}$ A los que se les proporciona la posibilidad de "celebrar sesiones de trabajo con todas las comodidades...y dar a sus empleados la posibilidad de gozar de unos días de descanso...y reponer sus energías".

${ }^{33}$ A los que se indica que hay que llegar a través de agencias de viajes y mayoristas. 
Una encuesta muy significativa realizada a clientes actuales y potenciales muestra que el aspecto más negativo que se señala por parte del grupo de edad de entre 45-60 años es el "excesivo número de personas de la tercera edad", dato que no señalan otras edades más tempranas, aunque este segmento es concretamente el que tiene mayor poder adquisitivo, un dato esencial para el "negocio" balneario ${ }^{34}$. Precisamente el precio es un "factor discriminante en el sentido de que segmenta la clientela en función de la situación económica" lo que impulsa una estrategia de sustitución de la clientela particular frente las "meras extensiones semi-públicas de la seguridad social o del Inserso" 35.

El director apuesta por una publicidad que comunique "un mensaje general de renovación, de acceso a nuevos públicos...además de tratar de limar la muy acentuada imagen de cutre y establecimiento decrépito, cuando no de sanatorio, que tienen[...] los balnearios". Según él, las empresas termales están "demasiado apegadas a su clientela tradicional[...]como centro terapéutico[...] demasiado obnubilados por el fenómeno Inserso". Finalmente hace recomendaciones sobre la prestación del servicio y sus controles (personal de contacto, información ${ }^{36}$, relaciones públicas, control de calidad, etc).

En 1998 el mismo autor publica un texto titulado "Estrategias competitivas para el sector balneario ${ }^{37}$ "(Vázquez-Illá 1998) en el que reflexiona sobre

${ }^{34}$ Negocio que desde muy temprano en este balneario ya mantenía diferencias sociales. Perucho indica (según el testimonio de Alejandro de Laborde) cómo hacia 1855 , poco después de pasar el balneario a manos privadas, mantenía diez balsas rectangulares o circulares donde podían tomar el baño de seis a doce personas al mismo tiempo. Una buena fonda servía la comida a los bañistas con dos modalidades: el servicio de primera clase, de diez y seis reales, daba por la mañana chocolate y al mediodía dos sopas, dos cocidos, tres entradas y postres, cena, cama completa y ropa limpia para el baño. El de segunda clase, de doce reales, sólo daba una sopa y dos entradas menos y en vez de cena se daba chocolate. Los enfermos los trasladaban sobre sus espaldas dos fornidos mozos-bañistas y el agua usada no se "volvía a aprovechar". Sus aguas eran útiles para reumáticos y venéreos (Perucho 1972: 34).

35 En la publicación de 1998 Vázquez-Illá se refiere a estos usuarios como el segmento "RR (reumático rico)" (1998: 58). En la actualidad (2008) la estancia en Arnedillo supera los 100 euros por persona y día, cantidad que se incrementa bastante más en los fines de semana. En Internet hay bastantes comentarios al respecto en relación a los excesivos precios de este balneario aunque se destaca su calidad. Quizá por ello, el Ayuntamiento de Arnedillo ha acondicionado en el río, fuera del balneario, unas piscinas naturales aprovechando unas pozas de agua termal que siempre han utilizado los vecinos. Allí acude la gente que no quiere o no puede pagar los precios del balneario.

36 Según el director en relación a la información hay que aplicar a los balnearios el adagio inglés "KISS (Keep it simple stupid) Hazlo de la manera más sencilla".

${ }^{37}$ En este momento Vázquez-Illá es vocal de la Junta Directiva de ANET (Asociación Nacional de Estaciones Termales) y su trabajo se dirige a los promotores y directores de balnearios. 
las causas del auge de los balnearios, trata de explicar mediante un análisis estructural, los principios sobre los que se asienta el sector, y sugiere las estrategias a seguir en el futuro. Vázquez-Illá señala el cambio de paradigma producido desde el viejo modelo (exclusivo uso del agua para tratamientos reumáticos o respiratorios, estancias largas, tercera edad, instalaciones espartanas, ausencia de instalaciones deportivas...) al nuevo modelo (el balneario como ocio, recuperación física y síquica, estancias breves, con usuarios urbanos y con trabajos estresantes). El nuevo modelo desde luego no sólo está en el ánimo del promotor. En este trabajo el autor se refiere a una encuesta realizada por Metra Seis sobre Estudio Producto Termal en la que la palabra Balneario se asocia con relax y puesta en forma en un $60 \%$ de la muestra mientras que sólo un 15\% lo asocia con curación o alivio de dolores. Del mismo modo lo que debería tener un balneario preferentemente, según esta encuesta, son los servicios de relajación y masajes además de una habitación bien equipada. Más de tres cuartas partes de los encuestados irían de vacaciones a un balneario. Estas características igualarían a los balnearios con los hoteles de salud y centros de talasoterapia e incluso clubes de fitness, competidores de los balnearios, pero si bien el balneario ha copado el segmento económico más bajo tradicionalmente ${ }^{38}$, se trata de dirigirlo al medio-alto de la demanda a base de vender "singularidad". En cuanto a los clientes hay dos tipos: por una parte los individuales, menos organizados y con poca capacidad de presión en los precios, y el cliente empresa u organización con más capacidad de imponer condiciones (tipo IMSERSO) y por tanto menos deseable. Por último señala las estrategias a seguir: el liderazgo en costes, la diferenciación y la especialización ${ }^{39}$.

Como se puede apreciar, la posición del director del balneario es similar a la del promotor decimonónico y su énfasis en el negocio balneario ${ }^{40}$. Por supuesto esto no es un demérito sino simplemente una perspectiva dentro de la organización balnearia. Y una perspectiva bien trabada y con una buena preparación, tal como se recoge en un reportaje del Diario $E l$ País (27/02/2005) que lleva el título de "Vender ocio además de salud".

\footnotetext{
${ }^{38}$ Según los datos de la encuesta sólo un $15 \%$ de los usuarios pagaría más de 10.000 pesetas por persona y día (1997) incluidos los servicios del balneario.

39 Esta última estrategia supone servir las necesidades de un determinado segmento: "el segmento podrá ser el RR (reumático rico) de toda la vida, el cliente que compra descanso, el que compra programas de belleza, fitness u otros, e, incluso los pequeños grupos de tercera edad [...] familias en vacaciones, empresas, grupos selectos [...]" (Vázquez-Illá 1998: 59).

${ }^{40}$ Del otro lado, desde la posición médica los escritos se refieren a la dimensión terapéutica como por ejemplo López Morales (2004) quien no suprime ciertas sospechas (Baud-Bovy \& Lawson 1998, Cherkin 1998).
} 
Vázquez-Illá es licenciado en Ciencias Políticas y Sociología y Master en Administración de Hoteles por la Universidad de Cornell (EE.UU) en los años noventa. Así explica el periodista el cambio producido recogiendo la opinión del propio director:

A mediados de los años noventa, Javier Vázquez-Illá volvió de EE UU para incorporarse al negocio familiar y ya entonces pensó en darle la vuelta. Su familia, agrupados en la sociedad Herederos Martínez Pinillas (sic), es la dueña del balneario de Arnedillo (La Rioja), el tercero o cuarto de España por facturación. El balneario marchaba esencialmente con reumáticos y con acuerdos con el Inserso para el tratamiento de la tercera edad.

Los planes de Vázquez-Illá supusieron la ruptura con el Inserso. "Me dijeron que estaba loco. En el sector me insultaron". Intentó la modernización de las instalaciones para hacer del balneario un lugar para toda la familia. "Se trataba de fusionar el concepto de balneario con el de spa americano", señala Vázquez-Illá tras insistir que debe ser un lugar lúdico, de relax y belleza, y terapéutico. Pero todo con agua termal o de mar y no del grifo. "Si me hubieran hecho caso desde el primer momento, seríamos casi un monopolio actualmente. Ahora otros centros han copiado el modelo, nos siguen", asegura (Gómez Damborenea 2005).

\section{ADENDA}

Cuando ya había redactado este artículo, en una última visita al Balneario de Arnedillo observé ciertas diferencias con años anteriores. En febrero de 2008 el Consejero-Director de Terma Europa Javier Vázquez Illá fue cesado de su cargo. Ese mismo año fundó TodoSpa, una empresa consultora para proyectos hoteleros con spa. La directora actual del Balneario ha realizado algunos cambios significativos, como la firma nuevamente (tras más de una década) de un convenio con el INSERSO. Sus primeros usuarios han llegado el 1 de febrero de 2009 y comparten el balneario con los clientes privados, si bien tiene un restaurante y menú, horario y actividades diferentes a éstos últimos. En el Programa de Animación de los mayores se encuentra la visita a un obrador de mermeladas y la exposición de menaje de cocina, baile, yoga, bingo, cartas, y una excursión. Ambos grupos no se mezclan, ya que los servicios del balneario para ellos tienen lugar entre 8 y 11 de la mañana, los horarios de comida y cena son más tempranos y su estancia en el balneario es por 11 días. Esta co-existencia que el personal del Balneario considera se debe a la necesidad de rentabilidad en temporada baja, ha supuesto también algunos pequeños cambios para los clientes privados, básicamente una menor disponibilidad del personal que debe dividirse (por lo que sólo hay una excursión y una sesión de cine al día, por ejemplo) y una ligera disminución de la calidad de los servicios y la alimentación, menos variada que anteriormente, si bien no ha habido subida 
de precio. En este cambio de perspectiva se alude a la necesidad de mantener los puestos de trabajo y especialmente a la omnipresente "crisis económica" pese a que el "negocio" hasta ahora parece haber sido rentable ${ }^{41}$. El cambio es demasiado reciente para poder apreciar su impacto en el futuro.

\section{CONCLUSIONES}

Pensar los pasajes en cuanto pabellones de balnearios. Nos gustaría dar con un mito de los pasajes que albergara una fuente legendaria en el centro[...] En estos clásicos deambulatorios en los que podría decirse que los pacientes avanzan paso a paso al encuentro de su curación, se experimenta hasta qué punto la cura constituye igualmente un rito de pasaje, la vivencia de una transición...

Walter Benjamín, "Lugares para la ensoñación, museos, pabellones de balnearios" (L 2, 6)

De las páginas precedentes se deduce el hecho de que estamos frente a tipos de balnearios diferentes: San Pedro do Sul y Curia, Ledesma y Arnedillo, son obviamente proyectos muy distintos que tienen en común las aguas termales pero poco más. Lo que es común en la definición del balneario es la fuerte ambivalencia entre la terapia y la vacación, el turismo y la medicina, las dos vertientes que ha caracterizado su propia historia.

Como he tratado de señalar en estas páginas los balnearios no conforman un único modelo, ni siquiera una mera dicotomía. La dimensión comparativa nos permite apreciar diversos grados, similaridades y diferencias, facetas, usuarios, edades. Los casos aquí señalados son etapas distintas, con diferentes énfasis, dentro del concepto ambivalente de balneario como sanatorio de la naturaleza-negocio turístico, y de sus diferentes usuarios viejos y jóvenes, ricos y pobres. La especialización del balneario en uno u otro sentido supone diferentes públicos, diversos colectivos sociales, planteamientos económicos y de clase dispares. Muestra también las modas terapéuticas, las costumbres sociales, la sociabilidad, el proceso de sustitución de usuarios y su incompatibilidad.

La clientela de San Pedro do Sul parece más homogénea y más cercana a Ledesma por la edad y situación de sus clientes. Curia ofrece un mayor contraste en su clientela por los tres tipos de asiduos (agüistas, veraneantes y practicantes de la forma física). El modelo de Arnedillo es equivalente a los veraneantes de Curia y (especialmente en los fines de semana) a los

\footnotetext{
${ }^{41}$ Así lo indican las cifras de 2007 en que Terma Europa superó los 15 millones de euros de ventas de los que 8.5 corresponden a los ingresos del Balneario de Arnedillo (http:www.slideshare.net/mcallan/terma-europa).
} 
practicantes de la forma física. Los jubilados de Ledesma comparten con los agüistas de Curia y San Pedro do Sul su condición física y social, si bien algunos de los más jóvenes activos utilizan el balneario como los veraneantes de Curia. Los cuatro modelos representan diversas modalidades: un balneario clásico como San Pedro do Sul que forma un fuerte contraste con un nuevo modelo, el Spa de Arnedillo, pasando por un establecimiento especializado en el colectivo minero, Ledesma, y unas termas mixtas, Curia, donde se aprecian (que no mezclan) diferentes grupos.

Esta variedad de los balnearios y sus diferentes clientelas reproduce sus oscilaciones a lo largo de la historia: desde la utilización local y los saberes populares de las aguas santas al placer cálido que supone para la realeza, nobles y aristócratas; desde la burguesía higienista en su época de máximo esplendor, la Belle Epoque, lugares de vacaciones de toda la familia, a los lugares de terapia de urbanos pobres y campesinos de la tercera edad, para terminar en las nuevas clases medias, que recuperan viejas ideas, la estética de una época y el refugio de un mundo lleno de stress.

Tras este cambio hay una reestructuración de las instalaciones balnearias adaptadas a los nuevos usos y colectivos, desarrollando nuevos servicios, instalaciones más lujosas o asépticas, y nuevos productos. Pero también ello es consecuencia de una nueva concepción del cuerpo y la apariencia, el body building y una preocupación por el cuerpo "exterior" frente al cuerpo "interior". Para el burgués, para la clase media, el agua es colateral mientras que para el pobre el agua es vital. En el traslado de la preocupación por la enfermedad a la salud, del cuerpo interior al cuerpo exterior, quedan fuera enfermos, viejos y pobres. Es muy significativo que sean precisamente los que están en el límite de edad (45-60 años) los más opuestos a la presencia de la tercera edad, quizá temerosos de lo que les espera. Dentro de esta diferencia de clases los balnearios eligen su decantación por el termalismo social o el termalismo de elite, por lo público o lo privado, por una intensa sociabilidad o una discreta y selectiva privacidad, por la seguridad de una clientela fija de programas sociales o por nuevas aventuras empresariales.

Pese al considerable peso de la medicina en la vida actual, su ingerencia en múltiples facetas y en el termalismo concretamente, desde hace muchos años, puede sugerirse que si bien en los balnearios tradicionales sigue teniendo su lugar con los usuarios de la tercera edad, en los nuevos modelos el poder médico ha perdido la batalla frente al promotor turístico, ya que se convierte simplemente en un "asesor de salud" en una consulta "light". Obviamente si el balneario se decanta por su vertiente turística, ¿quién necesita al médico en vacaciones? otros especialistas de puesta en forma, belleza y relax aparecen el paisaje balneario. La vieja pugna entre los pro- 
pietarios y los médicos que se dirime desde el siglo XIX se ha resuelto a favor de los primeros. Los documentos elaborados por Vázquez-Illá nos permiten adentrarnos en la planificación y configuración de un balneario moderno, son un testimonio de un complejo proyecto económico preciso y franco donde se condensan valores y símbolos de la más amplia sociedad.

\section{BiBLIOGRAFÍA CITADA}

Aguado Pintor, A. 2002. "La Isabela, un nuevo Real Sitio para los monarcas del siglo XIX". Espacio, tiempo y forma Serie VII, $\mathrm{H}^{\mathrm{a}}$ del Arte, t. 15: 229-253.

Bachelard, G. [1942] 1978. El agua y los sueños. México: FCE.

Baud-Bovy, M. y F. Lawson. 1998. Tourism and Recreation: handbook of planning and design. Oxford: Architectural Press.

Benjamín, W. 1996. "Lugares para la ensoñación, museos, pabellones de balnearios". Revista de Occidente 177: 114-31.

Bourdieu, P. 1988. La distinción. Madrid: Taurus.

Boyer, M. 1996. L'invention du tourisme. París: Gallimard.

Búrdalo, S. 2003. "El Ministerio de Fomento revitaliza los viejos establecimientos termales: Cura de juventud". Revista del Ministerio de Fomento 516: 30-35.

Castillo, S. 2008. "El tiempo que no(s) sobra. Prejubilación, morfología urbana y actividad en el contexto avilesino". Política y Sociedad 45 (1): 261-280.

Cátedra, María s/f (en proceso de publicación) "Prejubilados en el agua".

Caz Enjuto, Mํㅗ R. y M. Saravia. 1993. "De las entrañas de la tierra. Contribución al estudio de los balnearios decimonónicos". Historia Urbana (Valencia) 3:39-60.

Caz Enjuto, M ${ }^{\mathrm{a}}$ R. 2000. El agua en el seno de las aguas: la ordenación del espacio balneario en el Cantábrico. Valladolid: Universidad de Valladolid.

Cibeira Moreira, R. 2003. "El impulso del turismo de interior. El balneario de Mondariz y la gestión del gobierno local" en VV. AA. Geografía y gestión del turismo. VIII Coloquio de Geografía del Turismo, Ocio y Recreación: 201-211. Santiago: Universidad de Santiago de Compostela.

Cherkin, D. 1998. "Spa theraphy: panacea or placebo". Medical Care 36 (9): 1303-1305.

Colmenero, J. 1697. Tratado maravilloso y utilisimo de las enfermedades que se curan con las salutíferas aguas de los baños de Ledesma, con todas las observaciones que se requieren para el uso de ellas. Salamanca: Eugenio Antonio García,

Corbin, A. 1993. El territorio vacio: Occidente y la invención de la playa. Barcelona: Mondadori.

Durand, J. Y. 2003. "A diluiçâo do consenso: a agua, de "fonte de vida" a "patrimonio colectivo". Etnográfica VII (1): 15-31.

Featherstone, M. y M. Hepworth. 1991. "The mask of ageing and the postmodern life", en M. Featherstone, M. Hapworth y B.S.Turner (eds.), The Body. Social Process and Cultural Theory: 371-389. Londres: Sage Pub.

Feathestone, M. 1991. "The body in consumer culture", en M. Featherstone, M Hapworth y B.S.Turner (eds.), The Body. Social Process and Cultural Theory: 170-196, Londres, Sage Pub. 
Ferreira, Cl. 1994. Os usos sociais do termalismo. Práticas, representações e identidades sociais dos frequentadores das Termas da Curia. Tesis de Mestrado. Coimbra: Facultade de Economia de Coimbra.

Ferreira, Cl. 1995. "Práticas e representações dos Termalistas". Revista Crítica das Ciéncias Sociais 43: 93-122.

García García, J. L. 1996. Prácticas Paternalistas. Barcelona: Ariel.

García García, J. L. 2007b. "Las fronteras del estigma. De mineros y de prejubilados", en M. Cunha y L. Cunha (orgs.), Intersecçôes Ibéricas.Margens, Passagens e fronteiras: 227-249. Lisboa: Graus Editora.

García López, A. 1884. Monografía de las aguas y baños minerales de Ledesma. Madrid: Sucursal de Rivadeneyra.

Gil de Arriba, C. 2000. "La difusión social y espacial del modelo balneario: de la innovación médica al desarrollo de las prácticas de ocio". Scripta Nova 69 (40).

Gómez Damborenea, P. 2005. "Vender ocio además de salud. Terma Europa, con tres balnearios, aspira a doblar su tamaño". Reportaje ELPAIS.COM Negocios 27/02/2005.

Goubert, J. P. 1989. The conquest of water. The Advent of Health in the Industrial Age. Cambridge y Princeton: Polity Press.

Hembry, P. 1990. The English Spa, 1560-1815. A Social History. Londres: Athlone Press.

Hembry, P.1997. British Spas from 1815 to the present. A Social History. Londres: Athlone Press.

Illich, I.1989. H2O y las aguas del olvido. Madrid: Cátedra.

Jarrassé, D. 2002. "La importancia del termalismo en el nacimiento y desarrollo del turismo en Europa en el siglo XIX". Historia Contemporánea 25: 33-49.

Junta Directiva de la Asociación de Propietarios. 1874. Observaciones al Reglamento de Aguas Minero-medicinales de 12 de mayo de 1874 precedidas de las Exposiciones Presentadas al Gobierno antes y después de su publicación. Madrid: Imprenta de Manuel Minuesa.

Junta Directiva de la Asociación de Propietarios de Aguas Minero-Medicinales de España. 1910. "La libertad balnearia". Opúsculo.

Larrinaga Rodríguez, C. 2002. "El turismo en la España del siglo XIX". Historia Contemporánea 25: 157-179.

Leboreiro Amaro, Maㅗ A. 1994. El balneario: la ciudad ensimismada. Vigo: Colegio Oficial de Arquitectos de Galicia.

Leboreiro Amaro, Maㅗ A. 1991. "Balneario-Ciudad de las Aguas. Su presencia en España". Ciudad y territorio 89 (3): 213-229.

Leboreiro Amaro, Maㅗ A. 1996. A vida nos balnearios de Galicia. Vigo: Ir Indo Edicions.

Lenclud, G. 1984. "L'eau dans la cité. Techniques et milieu symbolique". Études Rurales 93-94: 151-161.

López de Azcona, J.M. 1966. Las aguas minerales en el libro del siglo XVII. Madrid: Instituto de España.

López Morales, M. 2004. "Los Balnearios como Centros de Salud". Index Enferm. [online], vol. 13, n. .47 , pp. 26-30. Disponible en: <http://scielo.isciii.es/scielo. php?script= sci_arttext\&pid=\$1132-12962004000300006\&lng=es\&nrm=iso $>$.

MacKman, D. P. 1998. Leisure Settings. Bourgeois culture, medicine and the spa in modern France. Chicago: Chicago University Press.

Marqués de Santa Marta, J. Gutiérrez de Ceballos, M. Matheu y otros. 1869. Exposición que los propietarios de baños de aguas minerales dirigen al Excmo. Sr. Ministro de 
Gobernación proponiendo bases para la reforma del derecho balnear. Madrid: Imprenta de la Avenida.

Martínez de Zalduendo, J. 1699. Libro de los Baños de Arnedillo, y remedio universal. Pamplona: Francisco Antonio de Neyra.

Montserrat Zapater, O. 1995. "La clientela balnearia de Panticosa (1826-1936)". Sociología del Trabajo 23: 129-154.

Montserrat Zapater, O. 1998. El Balneario de Panticosa (1826-1936). Historia de un espacio de salud y ocio en el Pirineo aragonés. Zaragoza: Gobierno de Aragón.

Montserrat Zapater, O. 2001. "Estudios recientes sobre la historia de los balnearios en España”. Sociología del Trabajo 43 (Otoño): 97-117.

Perucho, J. 1972. "Arnedillo, los lodos y Fernando VII". En Historias secretas de balnearios. Barcelona, Planeta.

Propietarios de Baños de Aguas Minerales (Marqués de Santa Marta, J. Gutiérrez de Ceballos, M. Matheu y otros). 1869. Exposición que los propietarios de baños de aguas minerales dirigen al Excmo. Sr. Ministro de Gobernación proponiendo bases para la reforma del derecho balneario. Madrid: Imprenta de La América.

Qintela, M. M. 1999. Curar e folgar: uma etnografia das experiencias termais nas Termas de San Pedro do Sul. Tesos de Mestrado em Antropología. Lisboa: ISCTE

Quintela, M. M. 2003. "Banhos que curam: práticas termais em Portugal e no Brasil". Etnográfica VII (1): 171-185.

Quintela, M. M. 2004 "Saberes e práticas termais: uma perspectiva comparada em Portugal (Termas do San Pedro do Sul) e no Brasil (Caldas do Emperatriz)". História, Ciencias, Saúde. Manguinhos Vol. 11, sup 1: 239-260.

Rauch, A. 1996. Vacances en France de 1830 à nos jours. Mesnil-sur-l'Estrée : Hachette.

Rodríguez Revilla, V. 1932. La propiedad de las aguas mineromedicinales. Madrid: Imprenta de Julio Cosano.

Rodríguez-Sánchez, J. A. 1997. "La supresión del cuerpo de médicos de baños (19321936)", en J. Castellanos Guerrero, La Medicina en el siglo XX: estudios bistóricos sobre Medicina, Sociedad y Estado: 269-280. Málaga: Universidad de Málaga.

Salgado, T. 1753. "Disertación que manifiesta las utilidades y daños de los Baños de Ledesma”, en L. Martínez Reguera. Bibliografía hidrológica-medica española, Parte Segunda, Tomo I: 33-35. Madrid: Sucursal Rivadeneyra.

Sébillot, P. 1983. Les Eaux Douces. París: Imago.

Torres Villarroel, D. 1988 [1752]. Uso y provechos de los baños de Ledesma. Edición preparada por Juan Francisco Blanco, Seminario Pintoresco Español y Museo de las Familias. Salamanca: Imprenta de Antonio Villagordo y Pedro Ortiz Gómez.

Towner, J. 1985. "The Grand Tour. A key phase in the history of tourism". Annals of Tourism Research 12: 297-333.

Valencia, M. A. 2006. "Agua que no has de beber... Antropología, género y patrimonio simbólico del agua". Cuadernos Abulenses 35: 309-343.

Vázquez-Illá, J. s/f (circa 1991-2) "Marketing externo e interno de un balneario" (http:// aguas.igme.es/igme/publica/pdjfor_aguas_mine16_marketing.pdf).

Vázquez-Illá, J. 1997. Estudio Producto Termal Metra Seis. Madrid: ANET-Futures.

Vázquez-Illá, J. 1998. "Estrategias competitivas para el sector balneario". Panorama Actual de las Aguas Minerales y Minero-Medicinales en España: 41-61 (http://aguas. igme.es/igme/publica/pdfart3/estrateg.pdf).

Vigarello, G. 1991. Lo limpio y lo sucio. La higiene del cuerpo desde la Edad Media. Madrid: Alianza. 
Vila, M. 1995. Los hoteles y el turismo de salud. Madrid: Vox Turismo.

Villa-amil y Castro, J. 1882. La policía balnearia según nuestros fueros municipales. Madrid. Wallon, A. 1981. La vie quotidiennne dans les Villes D'Eaux (1850-1914). París: Hachette.

Fecha de recepción: 14 de diciembre de 2008

Fecha de aceptación: 22 de febrero de 2009 